\title{
The Implementation of South Sumatera Downstream Industry for Rubber Product Strategic Policy with The Establishment of Tanjung Api-Api Special Economic Zone
}

\section{Sari Mutiara Aisyah}

Department of International Relations, Universitas Sriwijaya, Palembang, Indonesia sarimutiara@fisip.unsri.ac.id

\section{Yustian Yusa}

Department of International Relations, Universitas Sriwijaya, Palembang, Indonesia Nur Aslamiah Supli

Department of International Relations, Universitas Sriwijaya, Palembang, Indonesia

\section{O.K. Mohammad Fajar Ikhsan}

School of International Studies, Universiti Utara Malaysia, Malaysia

ikhsan@uum.edu.my

Submitted: 2 November 2020; Revised: 31 March 2021; Accepted: 5 May 2021

\begin{abstract}
Abstrak
Opsi hilirisasi untuk memberikan nilai tambah pada industri lokal terutama negara berkembang pada era rantai nilai produksi global atau Global Value Chain (GVC) sebagai cara meningkatkan daya saing dan merebut pasar global merupakan hal yang tak terhindarkan. Penelitian ini fokus pada analisa perkembangan dan keterbatasan yang dihadapi dalam implementasi Kebijakan Strategis Hilirisasi Produk Industri Karet Sumatera Selatan dengan ditetapkannya Kawasan Ekonomi Khusus (KEK) Tanjung Api-Api. Kajian ini menggunakan metode penelitian kualitatif yang bersifat deskriptif, dimana kedalaman dan konteks data menjadi penting. Metode pengumpulan data adalah teknik yang dapat digunakan peneliti untuk mengumpulkan data primer melalui wawancara dan observasi lapangan sekaligus data sekunder melalui telaah dokumentasi. Temuan sementara peneliti dilapangan bahwa hilirisasi produk industri karet di Sumatera Selatan belum maksimal dilakukan, masih tersegmentasi tidak dikerjakan secara efisien atau satu garis produksi dan kebijakan strategis pengembangan industri tidak memiliki roadmap yang jelas dan berkelanjutan. Kawasan Ekonomi Khusus (KEK) tanjung api-api sebagai hub perdagangan internasional dan industrialisasi komoditas karet juga ditemui berbagai hambatan diantaranya infrastruktur (deep seaport) di titik ini tidak memadai, kepastian insentif fiskal bagi perusahaan yang relokasi ke KEK, Perizinan dan efisiensi birokrasi antara Pemerintah Pusat dan Daerah.

Kata Kunci: Rantai Nilai Global, kebijakan hilirisasi industri karet, Kawasan Ekonomi Khusus.
\end{abstract}

\begin{abstract}
The downstream option to provide added value to local industries, especially developing countries in the Global Value Chain (GVC) era, to increase competitiveness and seize global markets is inevitable. This paper analyzed the developments and limitations faced in implementing the Strategic Policy of South Sumatra Rubber Product Downstream with the establishment of Tanjung Api-Api Special Economic Zone (SEZ). This study used a descriptive qualitative method, where the depth and context of the data are essential. This study utilized two data types; secondary data collected through literature study and analysis of documents and primary data obtained from interviews and field research. The authors concluded that the downstream industry of rubber products in South Sumatra has not been maximally carried out. There was an inefficient production lines as they worked at different phase or segment. The strategic policy were both unsustainable and no clear roadmap. Tanjung Api-Api SEZ, as a hub for international trade and industrialization of rubber commodities, also encountered various obstacles, including inadequate infrastructure (deep seaport), the certainty of fiscal incentives for companies relocating to SEZ, licensing and bureaucratic efficiency between national and local governments.

Keywords: Global Value Chain, Rubber Industry Downstream Policy, Special Economic Zone.
\end{abstract}




\section{INTRODUCTION}

Global Value Chain (GVC) is a new trend in international trade, where the basis for value-adding activities from raw materials to finished goods and consumers is carried out in inter-firm networks on a global scale. As stated by Gereffi and Frederick (2010), the GVC framework to describe global production, analyze added value creation in supply chains, and provide answers to questions related to trading, competition, and development, has gained a lot of traction in the last few decades. In addition, the uncertainty of global market demand and price is also a challenge for policymakers, although there has been an increase in the contribution of global value-added trade from developing countries from $20 \%$ in 1990 to $30 \%$ in 2000 , and more than $40 \%$ in 2010 ; it is a fact showing the penetration results of GVC in emerging markets (UNCTAD, 2013).

The Association of Southeast Asian Nations (ASEAN) has emerged as a powerful trading bloc in global trade. The ASEAN Integration Report (2019) asserted that ASEAN is in the top five of the world economy with a Gross Domestic Product (GDP) of around USD 3 Trillion; it increased significantly from the seventh position in the past five years. One of the leading export commodities of ASEAN member countries is rubber; three of the five highest natural rubber producers in the world are from ASEAN, as shown in the table below:

Table 1. The Largest Natural Rubber-Producing Countries in 2018

\begin{tabular}{ccc}
\hline No & Countries & Production (In ton) \\
\hline 1 & Thailand & $5,145,000$ \\
\hline 2 & Indonesia & $3,486,000$ \\
\hline 3 & Vietnam & $1,137,700$ \\
\hline 4 & China & 820,000 \\
\hline 5 & India & 660,000 \\
\hline
\end{tabular}

Note. Data retrieved from ANRPC (2018)

The development of rubber production export in Indonesia still relies on natural and synthetic rubber products. Natural rubber is Indonesia's second-highest non-oil and gas export commodity and contributed $5.17 \%$ to GDP in 2018 , increasing by $3.5 \%$ from the previous year and in the last five years. The average export in 2014-2018 was 2.72 million tons for natural rubber and 29.84 million tons for synthetic rubber. South Sumatra was the highest contributor and producer of rubber in Indonesia in 2014-2018, with an average production of 1,036.96 thousand tons. The number of rubber production is also related to the area of land available for rubber plantations. The total area of Indonesian rubber plantations has increased steadily over the past decade. In 2016, rubber plantations in the country reached a total area of 3.64 million ha. Due to the positive prospects for the rubber industry, there has been a shift from commodity plantations such as cocoa, coffee, and tea to oil palm and rubber plantations, and almost $80 \%$ of this land area is owned by farmers (BPS, 2019).

The enthusiasm in the export of natural rubber products has undoubtedly become a unique potential for Indonesian state revenues. However, due to some conditions below, Indonesia's position as an exporter of raw and semi-finished raw materials is no longer a strategic choice for this country to compete competitively in the international market, which impacts the welfare of small farmers as the main producers. Syarifa, L. F., \& Tistama, R (2020) stated that Indonesia is only a price taker in determining the price. Therefore, domestic prices are in line with world rubber prices. Slab lump is a 
type of natural rubber mainly produced $(99 \%)$ by rubber farmers in Indonesia. During 2013-2017, the slab lump price declined by $8.48 \%$. As the primary producer of natural rubber, which controls $90 \%$ of total world rubber production, and involves members from Indonesia, Thailand, and Malaysia, the International Tripartite Rubber Council (ITRC) agreed to reduce rubber exports through the Agreed Export Tonnage Scheme (AETS) in October 2012- March 2013 and 2016 to increase the price. Unfortunately, the result was not significantly impactful. The trend of rubber prices (TSR 20) on the Singapore Comodity Exchange (SICOM) exchange in 2015-2020 continued to decline by $0.44 \%$ per year but fluctuated from year to year.

The decline in rubber prices is due to various factors: one of the major reasons is because China dominates world rubber consumption. China's economic condition is slowing down due to the trade war with the United States (US). China's economic growth is the main factor affecting the demand for natural rubber in the world. It makes China issue a policy to reduce demand to Indonesia, even though China is the third-largest trading partner as the export destination country for Indonesian rubber products. Excess supply in the export market is due to the emergence of new producing countries for rubber commodities such as Myanmar, Laos, and Cambodia. Previously, natural rubber production was only supported by six countries: Thailand, Indonesia, Vietnam, Malaysia, India, and China (CNN Indonesia, 2019). The momentum above can be taken as an opportunity for Indonesia to begin substituting imports and downstream rubber commodities for other industrial sectors' sustainability.

Investment is essential in today's world economy to encourage the development of the intermediate or final goods processing industry. ASEAN member states have been promoting SEZ as a cornerstone effort to encourage more foreign investment and consolidate its emergence as a powerful trading bloc. The idea of developing SEZ raised since the establishment of The ASEAN Investment Forum on November 16, 2011, improving the investment climate in the Southeast Asian region and realizing ASEAN as a single market and production base as one of the components of the 2015 ASEAN Economic Community (Kompas, 2011). In its implementation, each ASEAN member country adopts different strategies due to different levels of competitiveness; for example, Vietnam relies heavily on industrial parks to attract foreign investment, and Singapore has designed one-north Singapore, the first innovation district in the ASEAN. Even so, the state's steps in developing Economic Zones should ideally be able to determine the position and form of economic zone development and strategies to increase competitiveness (ASEAN Guideline for SEZ, 2016).

Tanjung Api-Api in South Sumatra Province is one of the SEZs in Indonesia designated through the Indonesian Government Regulation Number 51 of 2014. Tanjung Api-Api SEZ has geo-economic advantages because it is in the highest rubber and palm oil-producing region. The area is prepared to maximize industrial activities, export, import, and other economic activities with high economic value and specialization in production. Unfortunately, initial field observations discovered the slow development of the SEZ in Tanjung Api-Api, initially planned in 2014 with an estimated development of five years, so it should be completed in 2018, as stated in the work plan timeline by The Development Planning Agency at Sub-National Level in South Sumatera (BAPPEDA Sumsel, 2011). However, until 2020, the process of developing special economic zones is still in land cleaning and far from the ready condition.

This study is interesting as it focuses on the implementation of the downstream strategic policy for rubber industry products in South Sumatra by establishing Tanjung Api-Api SEZ. The researchers began the discussion by mapping the modes of the rubber absorption value chain from South Sumatra to the international market to determine the level or position of value-added activities for the rubber processing industry-especially in South Sumatra-, and explain the opportunities and obstacles for the development of the Tanjung Api-Api SEZ. 


\section{LITERATURE REVIEW COUNTRY POSITIONING IN GVC: DOWNSTREAM AS A FORM OF INDUSTRIAL POLICY}

The emergence of a GVC and a new form of trade recommends various revisions of public strategic policies aimed at regulating competitiveness as well as trade and large-scale development policies. Three paradigm shifts can be used as a reference (Cattaneo and Miroudot, 2013): 1) Changes in a relevant strategic framework, from state-based to company and GVC. The competitiveness strategy must be adapted to suit trade and industry organizations. Policymakers need to think business globally, or at least regionally. A country cannot develop a competitive supply of goods or services separately. It implies that imports are not an expression of foreign competitiveness but rather a means for companies to access the most efficient inputs and the certainty of resources to focus on core competencies. Adjusting to business practice, policies must treat trade and FDI, both inward and outward, in an integrated framework; 2) Changes in the relevant economic framework, from industry to business tasks and functions. The aim is not to develop a domestic industry that will capture all production segments or the entire value chain, but to identify the country's best position in the GVC and the most competitive offering of the job or business function; and to recognize that an efficient manufacturing sector requires efficient and competitive services and a skilled workforce and continuous innovation in products, processes and business models. Services such as financial intermediation, $R \& D$, logistics, and marketing are required to produce high value-added manufacturing.

Muradov (2017) emphasized that countries naturally differ in where they are located in the value chain. Upstream position in the value chain means that most production requires primary inputs, and outputs are supplied to intermediate users. It is typical for producers of raw materials or knowledge (e.g., research, design) required at the beginning of the production process. Downstream position means that production requires more intermediate inputs, and outputs are supplied to final rather than intermediate users. Producers located downstream tend to specialize in assembling processed goods and providing customer services. The relative position in the GVC can change over time. Therefore, moving upstream or upgrading the country's position in GVC is a current policy priority for many countries. The fact detailed in the background about the price volatility imposes that the export commodity of natural rubber and the surplus in natural rubber availability causes the unsustainable state revenue and productivity of this commodity. The most affected actors are business stakeholders whose plantation is $80 \%$ owned by smallholders. The downstream option for natural resource-based industries is imperative for the government to prioritize. A position closer to the beginning of the production process is generally believed to secure higher value-added shares and increase technological sophistication (OECD, 2013).

The value chain concept also recognizes that production must be related to demand and plays an essential role in regulating the flow from farmers to potential consumers (Porter, 1985). Porter's value chain analysis consists of main and supporting activities. The primary activity directly affects the production, maintenance, sale, and support of the product or service. The activities consist of the following elements:

Several factors affect investment decisions and join the GVC summarized by (Cattaneo et al., 2013). Several constraints can hinder a country's participation in a GVC, whether related to connectivity to international markets, ease of doing business and investing, or capacity to respond to the demands of leading companies. It also provide additional details about the perceptions by the lead firms about the factors that positively and negatively affect the source and investment decisions in GVC. Some of these factors are exogenous (e.g., market size and proximity), but others can be positively affected by correct policy decision. The costs (production, labor, transportation, investment, and tax incentives) are the main drivers of the decisions of the main companies to invest or source of production in developing countries. However, workforce development and productivity gains associated with innovation should be encouraged. The increased connectivity with international markets has regulatory 
and infrastructure dimensions. It is about enhancing the forward and backward linkages within the GVC, securing input and output flows, and creating efficient links with global markets. It also reduces "border thickness" (OECD, 2013) and includes reducing traditional obstacles to trade and promoting trade facilitation.

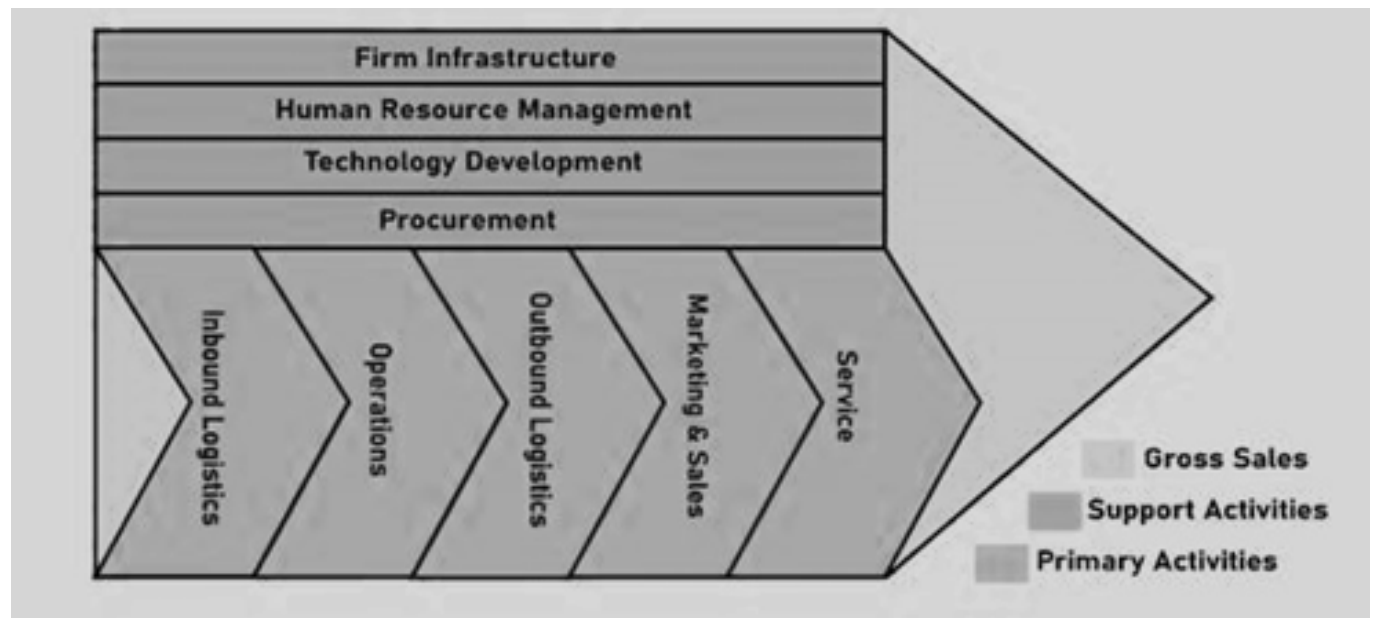

Figure 1. Porter's Value Chain (1985)

\section{DOWNSTREAM INDUSTRIAL POLICY: INITIAL STAGE TO ORDER SEZ}

Industrial policy can be defined as government efforts that focus on promoting and strengthening specific industrial sectors through a series of policy frameworks to change industrial structures to promote productivity-based growth (Low \& Tijaja, 2013). The industry maximization process must be supported by government policies that focus on economic growth. One form of policy offered in (Low \& Tijaja, 2013) is industrialization based on a resource (downstream). Downstream is an action to minimize the export of raw materials and increase the use of these materials to maximize value-added once the export is carried out on these commodities' processing (Pantunru, 2015). The state policy in the downstream context is the most appropriate initial policy to maximize the export process for certain commodities. This policy can increase the country's export income, fiscal income and possibly provide new job prospects for citizens. On the other side, the downstream policy is difficult to implement due to several factors, such as low investment levels in value-added processes, low domestic capacity to process commodities, and additional costs (Östensson, 2020).
Singapore is one of the countries capable of realizing downstream policy. The oil commodity development sector is the primary sector developed by Singapore with providing value-added in the downstream process. Strengthening downstream policy in line with increased investment in essential commodities is a method used by Singapore to increase the country's export income. This success cannot be separated from two other crucial things: political will and cohesion policy from the downstream industry (IGF, 2018). In another case, the success of downstream policy in China for agriculture is supported by the high level of investment from the downstream commodity process (Zeng, 2012). The downstream policy can be the initial policy in ordering SEZs to accelerate the economic growth of a country. However, it should be noted that determining the location of SEZs is very important. The track record of SEZs in the southern African region with agriculture commodity and planning errors in the determination of SEZs have become a weakening in the maximization of SEZs that impact slow economic growth (Dube, Mastika $\&$ Chiwunze, 2020). 


\section{RESEARCH METHOD}

This study employed a descriptive qualitative method. This method uses data findings, elaborates concepts as analysis tools, concludes the data, and synergizes with the concepts used. This study used primary data, which were the elaboration of in-depth interviews with the Indonesian Rubber Association (GAPKINDO) in South Sumatra, the Tire Industry Company, PT. SMS (BUMD) and also the Local Government. These primary data were supported by secondary data regarding rubber production (2014-2018), export of natural rubber (2014-2018), domestic demand for natural rubber (2014-2018), government policies related to rubber (agro-industry), and literature in scientific journals, books or reports supporting this research. The findings of primary and secondary data were then grouped into data needs, which were the focus of this study. The next stage was to interpret the data presented with the linking concept used. Then, the presented data were converged on the conclusions, containing the answers to the studied phenomena.

\section{RESULT AND ANALYSIS GOVERNMENT AS CATALYST: DOWNSTREAM POLICY OF RUBBER INDUSTRY}

Two unsustainable downstream industrial policy programs caused unclear Indonesia's position regarding the downstream of the natural rubber processing industry. Thus, as the highest natural rubber-producing province in Indonesia, South Sumatra has not received significant benefits. Indonesia remained an exporter of raw materials for rubber products by $79 \%$, and the remaining $21 \%$ was absorbed by the domestic market, of which $65 \%$ was absorbed by value-added processing of the large tire industry. It has not changed much since Fauzi (2013) mapped Indonesia's position weakness, even before the two policy packages for this program were formulated. First, in 2012, the Ministry of Industry in the MP3EI program (2012-2025) announced a road map for the development of natural rubber into spare parts for transportation equipment in the Tanjung Api-Api industrial area, Banyuasin Regency, South Sumatra Province (Bappenas, 2011), officially stipulated through an Indonesia Government Regulation Number 51 of 2014. The drafting of this roadmap is still in the initial stage or seed stage. This declaration was based on a research plan conducted by Nasruddin et al. (2012) from the Agency for the Study of Policy, Climate, and Industrial Quality, the Institute for Industrial Research and Standardization in Palembang.

The main argument in the preparation of the road map is related to Indonesia as the second-largest rubber-producing country in the world and South Sumatra as one of the largest natural rubber-producing regions in Indonesia. However, the export of crumb rubber did not provide higher economic benefits for the

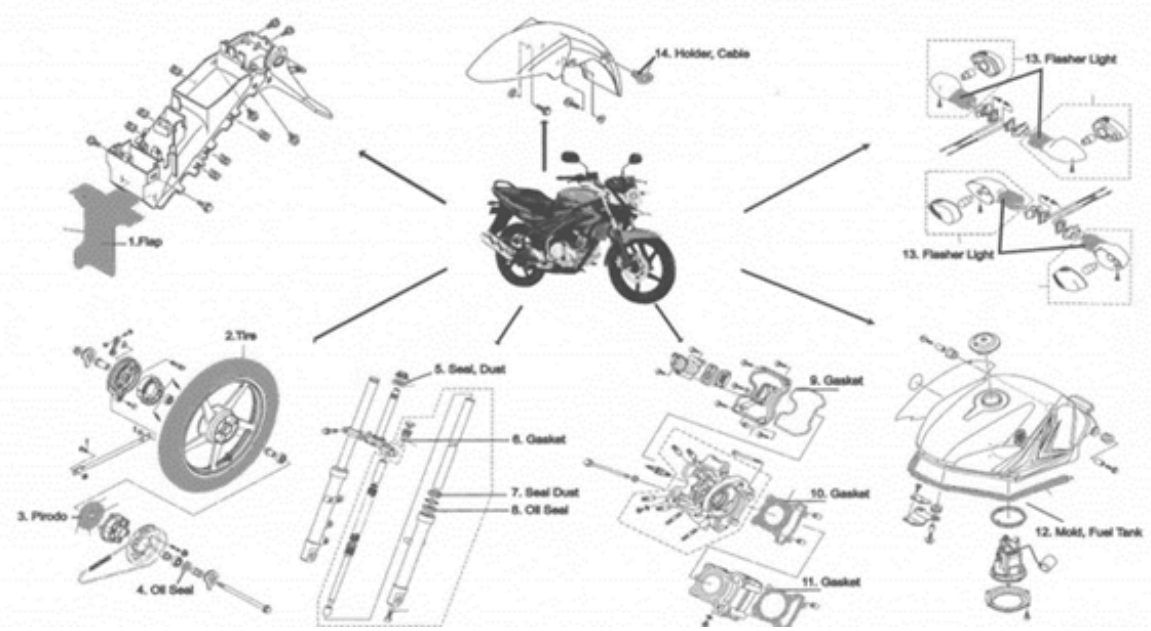

Figure 2. Rubber Spare Parts for Two-Wheeled Motorized Vehicles (Nasruddin et al., 2012) 
community and foreign exchange. On that basis, to improve crumb rubber into a highly competitive downstream (value-added) industry, there must be continuous focused technology and research following the priority scale to be achieved. The downstream industrial road map plan in its grand design relates to the automotive industry (see Figure 2).
Second, the national industrial development strategy has been carried out by developing upstream and intermediate industries based on natural resources under the grand plan of national Industrial Development (RIPIN) 2015-2035. The rubber processing industry, both natural and synthetic, is intended to support the supporting material industry from the prioritized industry of oil, gas, and coal-based basic chemical.

Table 2. Type of Industry at the Development Stage of the Natural and Synthetic Rubber Industry

\begin{tabular}{|c|c|c|c|}
\hline \multirow{2}{*}{$\begin{array}{l}\text { Prioritized } \\
\text { Industry }\end{array}$} & \multicolumn{3}{|c|}{ Type of Industry } \\
\hline & $2015-2019$ & $2020-2024$ & $2025-2035$ \\
\hline & \multicolumn{3}{|c|}{ Natural and Synthetic Rubber Industry } \\
\hline $\begin{array}{l}\text { Oil, Gas and } \\
\text { Coal-Based } \\
\text { Basic Chemical }\end{array}$ & $\begin{array}{l}\text { 1. Butadiene Rubber (BR) } \\
\text { 2. Styrene-Butadiene } \\
\text { Rubber (SBR) } \\
\text { 3. Engineering natural } \\
\text { rubber compound }\end{array}$ & $\begin{array}{l}\text { 1. Isoprene Rubber (IR) } \\
\text { 2. Acrylonitrile Butadiene } \\
\text { Rubber (ABR) } \\
\text { 3. Chloroprene Rubber (CR) } \\
\text { 4. Ethylene Propylene Diene } \\
\text { Monomer (EPDM) } \\
\text { 5. Engineering natural } \\
\text { rubber compound } \\
\text { 6. Acrylonitrile Butadiene } \\
\text { Styrene (ABS) }\end{array}$ & $\begin{array}{l}\text { 1. BR } \\
\text { 2. SBR } \\
\text { 3. IR } \\
\text { 4. ABR } \\
\text { 5. CR } \\
\text { 6. EPDM } \\
\text { 7. Engineering } \\
\quad \text { natural rubber } \\
\quad \text { compound }\end{array}$ \\
\hline
\end{tabular}

Note. Data adapted from Kemenperin (2015)

To achieve national industrial development target, prioritized industrial development programs must be carried out along with the government, state-owned enterprises, and the private sector. Prioritized industrial development programs during the 2015-2019 and 2020-2035 period, especially in the natural and synthetic rubber industry, were compiled as follows:

Table 3. Prioritized Industrial Development Programs for Upstream-Downstream of Rubber Product

\begin{tabular}{l|l}
\hline \multicolumn{1}{c|}{$2015-2019$} & \multicolumn{1}{c}{$2020-2035$} \\
\hline $\begin{array}{l}\text { Facilitating the establishment of industrial } \\
\text { factories for BR, SBR, IR, ABS, and }\end{array}$ & $\begin{array}{l}\text { Encouraging the development of national } \\
\text { technology to produce synthetic rubber; }\end{array}$ \\
$\begin{array}{l}\text { EPDM in Cilegon, Banten; } \\
\text { Facilitating the market opening of } \\
\text { synthetic rubber industry through } \\
\text { upstream-downstream cooperation; }\end{array}$ & $\begin{array}{l}\text { Facilitating the development of a } \\
\text { large-scale synthetic rubber industry with } \\
\text { an export orientation; }\end{array}$ \\
\hline
\end{tabular}

Note. Data adapted from Kemenperin (2015) 
The centralization issue of the natural and synthetic rubber processing industry is getting more festive, as shown from the RIPIN 2015-2035. The establishment of a processing factory to support the rubber industry is focused in Java, leading to the less maximal investment growth and labor absorption from the natural resource processing sector in South Sumatra because the downstream sector with the highest absorption is in the tire industry and many of which operate in Java. Arsyad (2020) as the general manager of PT. Bridgestones Indonesia and the manager of Kumho Tire Area (South Korea) revealed that as his experience at Bridgestone, the company took 140 tons of raw materials from PTPN 8 (state-owned enterprises) in Sukabumi per day. Purchase contracts were in US Dollars, not in Rupiah. At that time, the company wanted to take rubber from Jambi, but trade between islands was not allowed. The assumption was that because PTPN consisted of 14 companies, they implemented a "market share". Hence, with Bridgestone Indonesia's factories in Bekasi and Karawang (Java Island), according to economic considerations, it was more economical to source raw materials close to the factory, which was Sukabumi (PTPN 8). The contract duration for the purchase/procurement of raw materials was a year and could be extended with a new contract (see figure 5).

The commitment of the national government related to the establishment of a natural resource-based manufacturing development sector, especially the rubber commodity, continued to change, and there was no clear roadmap of industry priorities. In the first design, the downstream policy of the rubber industry in South Sumatra has concentrated industrial activities in the Tanjung Api-Api SEZ as a form of integrated strengthening to the downstream sector, increasing exports of finished goods for the automotive industry. Therefore, a change occurred in the government regime; under the RIPIN 2015-2035. Indonesia has changed the priority of natural rubber absorption into a supporting/intermediary industry for natural and synthetic rubber, included in the petrochemical type, and the factories will be entirely located in Java.

\section{EFFICIENCY OF RUBBER VALUE CHAIN}

To create the optimization of rubber products with added value and high competitiveness, an efficient network of stakeholders in rubber commodities is needed. These networks must interconnect and add value to commodities in each phase. In the upstream sector, rubber plantations were owned by people or companies. The data from the Central Bureau of Statistics (BPS, 2019) showed that the highest contribution to rubber production was from smallholder plantations (PR), with $85.27 \%$ spreading throughout Indonesia, while $8.14 \%$ belonged to private plantation enterprises (PS) and the remaining $6.54 \%$ belonged to state-owned plantations enterprises (PN). In the upstream sector, South Sumatra had the largest smallholder plantation in Indonesia, namely 787.9 thousand ha (25.39\%) in 2017 of the total area of PR rubber in Indonesia, and in 2018 it was estimated at 788.77 thousand ha (25.33\%). Indeed, to produce high-quality rubber, it must start with the provision of seeds, soil optimization, and various other forms of engineering. It should be the focus and attention of the central government through the Ministry of Industry, Ministry of Trade, Ministry of Research and Technology/BPPT, LIPI, and National Standardization Agency. In the upstream sector, the rubber farmer group must have treated the seeds following the Standard Indonesian Rubber (SIR 20, 10, 5) to be properly absorbed by the factory (Table 3). The shrinking SIR determined the good quality of the rubber. Thus, it can be accepted by the international market.

The authors constructed three modes of the existing downstream production value chain for the rubber-based processing industry. Two flow positions as the upstream industry (Figures 3 and 4) were conducted in South Sumatera, and another flow position as the downstream industry (Figure 5), which was the ideal ones. It showed an inefficient production line as they worked at different phase-not integrated. Two of them were focused on the area of South Sumatra, which was limited to the operations of raw and semi-finished goods. Another value chain flow described the downstream activities carried out by large industries to the downstream sector of processed rubber products, specifically tire products 
Table 4. List of Rubber Factories in South Sumatra

\begin{tabular}{|c|c|c|}
\hline No & Name & Production \\
\hline 1. & $\begin{array}{l}\text { HOKTONG, PT } \\
\text { Jl. Sei, Bunut, Palembang, Sumatera Selatan }\end{array}$ & Rubber SIR \\
\hline 2. & $\begin{array}{l}\text { JULANG OCA PERMANA, PT } \\
\text { Jl. Poros Transmigrasi Km.25 Ds. Iv Desa Jadi Mulya 1, Musi Rawas } \\
\text { Utara, Sumatera Selatan }\end{array}$ & Rubber SIR \\
\hline 3. & $\begin{array}{l}\text { LUBUK LANCANG KUNING, PT } \\
\text { Jalan Padat Karya Desa Lubuk Lancang, Banyu Asin, Sumatera Selatan }\end{array}$ & Rubber \\
\hline 4. & $\begin{array}{l}\text { MELANIA INDONESIA, PT } \\
\text { Jl. Palembang Betung Km. 35, Banyu Asin, Sumatera Selatan } \\
\text { Telp. } 0711 \text { - } 313200\end{array}$ & Rubber \\
\hline 5. & $\begin{array}{l}\text { PINAGO UTAMA, PT } \\
\text { Jl. Basuki Rahmat Nomor 23, Palembang, Sumatera Selatan }\end{array}$ & Rubber \\
\hline 6. & $\begin{array}{l}\text { PP LONDON SUMATRA INDONESIA, TBK., PT } \\
\text { Jalur Lintas, Ogan Komering Ilir, Sumatera Selatan }\end{array}$ & Rubber \\
\hline 7. & $\begin{array}{l}\text { PP LONDON SUMATRA INDONESIA, TBK., PT PABRIK } \\
\text { MESUJI/MAKP }\end{array}$ & Rubber \\
\hline 8. & $\begin{array}{l}\text { Kabupaten Ogan Komering Ilir, Ogan Komering Ilir, Sumatera Selatan } \\
\text { PTP NUSANTARA VII KEBUN MUSI LANDAS } \\
\text { Jl. Raya Palembang-betung Km. 20, Banyu Asin, Sumatera Selatan }\end{array}$ & Rubber SIR 20 \\
\hline & $\begin{array}{l}\text { PTP NUSANTARA VII UNIT PABRIK KARET BA } \\
\text { Desa Lengkis Rejo Batumartalii, Ogan Komering Ulu, Sumatera Selatan } \\
\text { Telp. } 0735-325777\end{array}$ & SIR 20 \\
\hline & $\begin{array}{l}\text { PTP. NUSANTARA VII UU TEBENAN } \\
\text { Jl. Raya Km. } 75 \text { Desa Suka Mulya, Banyu Asin, Sumatera Selatan } \\
\text { Telp. } 0711 \text { - } 893786\end{array}$ & Rubber SIR 20 \\
\hline
\end{tabular}

Note. Data adapted from (Kemenperin, 2020)

centralized in Java and highly depended on the broker to import some unavailable raw materials. It will discuss further in the next sub-discussion.

First, the mode of local rubber uptake in South Sumatra is followed by private companies/factories (see Figure 3). If we look at the figure, management in this sector cut off the relationship between rubber farmers (smallholders' plantations) as suppliers of raw materials and private factories/companies (midstream sector). Farmers do not directly communicate with the factory and only sell to the highest bidder of the rubber and then pass it on to the factory. According to Ahmadi (2020), as the Executive Secretary of the South Sumatra branch of the Indonesian Rubber Companies Association
(GAPKINDO), the company did not directly buy raw rubber materials from farmers, but from suppliers or rubber collectors brought to the factory and ready for further processing. The rubber processing material (Bokar) was processed to meet the Standard Indonesian Rubber (SIR), with SIR 10 and 20 depending on the request of the buyers, generally tire manufacturers. There was no quality control system for raw materials that bound between the factory and the farmers. The factory also complained about the quality of raw materials received from suppliers for not meeting the standard and affecting the efficiency of the performance of value-added operations of intermediate goods by the factory. Besides, the investment of rubber farmers on quality 
improvement of raw material was also increasingly neglected because their orientation was limited to only being sold to the higher bidder. In fact, the upstream sector would produce rubber trees, synthetic rubber, fillers, and it required the provision of machinery and equipment, as has been done by the Musi Banyuasin District Government by providing a centrifuge machine in collaboration with the private sector, Jaya Trade.

Lack of technology, research, and development also impacted the fluctuating demand and price of crumb rubber, and the buyer country determined the price. In this case, the link was the Singapore broker (SICOM), taking over the distribution and marketing function of semi-export products. Thus, rubber as an agricultural commodity was highly dependent on science and technology and applied production management. Also, rubber industry products must be adapted to the needs of the changing market demands. As Indonesia is one of the largest rubber-producing countries, we cannot determine the selling price of rubber. When the world economy improves, the demand for natural rubber and prices set by global buyers is also high and vice versa. It was not surprising that Indonesia's natural rubber exports based on destination countries, previously doubled in 2017 by 922.8 (000) tons, fell by almost half in 2019, and became 440.6 (000) tons due to the world economic recession. In addition, the offering price was the result of lowering the supply by factories to the bidder (rubber collectors) and rubber farmers. The more actors involved as the middleman in the transaction, the smaller the price received by rubber farmers. It was the reason why the offering price for rubber to farmers in each region was different.

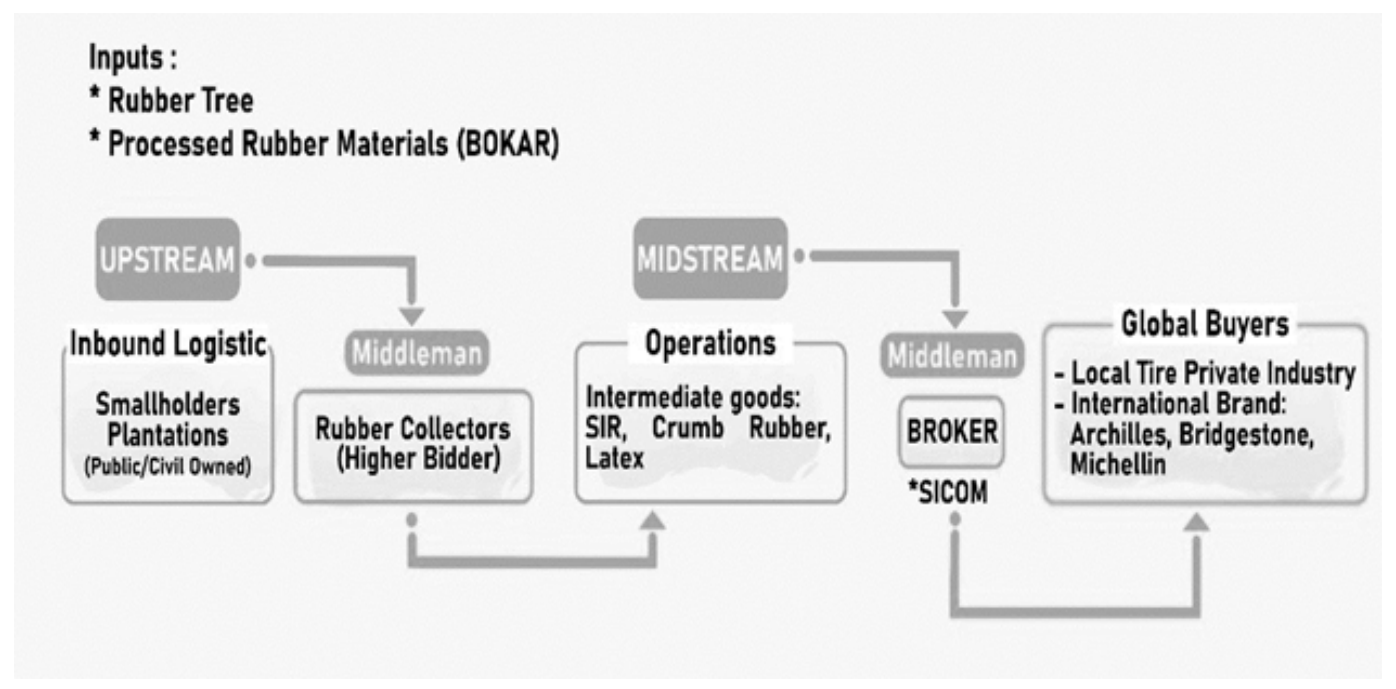

Figure 3. Rubber Value Chain by Private South Sumatra Companies (Ahmadi, 2020)

Second, similar to value chain activities in private factories, the existence of PT. Perkebunan Nusantara VII, as a state-owned company with its head office in Bandar Lampung, with operational areas covering South Sumatra, Lampung, and Bengkulu, also did not include technical assistance about rubber plant cultivation upgrading for smallholder plantations in partnership and environmental development programs. If there is any assistance activity (advocation) or technical consultation, it is done incidentally and based on local government requests. It was delivered by Okta Kurniawan, the Senior
Executive Vice President Business Support, who emphasized that rubber farmers were not competitors but partners who would benefit mutually in a healthy company condition (Sumatera Post, 2020). However, natural rubber was absorbed by the farmers not as much as from the company's rubber cultivation business unit; thus, the supply-demand relationship was impermanent and unsustainable. Unlike the previous mode, there was upgrading in the PTPN 7 value chain where all the products produced, although still in semi-finished goods, have met the SIR 20. Moreover, selling and promoting 
the export of semi-finished goods from the PTPN network were carried out by an export company specializing in plantation products, namely PT. Kharisma Pemasaran Bersama Nusantara.

After having value-added in the midstream sector, how could these products be absorbed in the international market? The role of associations such as GAPKINDO and KADIN was needed, which synergized with local governments and related agencies. Ahmadi (2020) stated that most companies exporting rubber products were still in semi-finished goods or SIR 20. Destination countries covered the United States, China, Africa, and several multinational tire companies, such as Achilles, Bridgestone, and Michellin. The company preferred to remain engaged in the production of semi-finished goods, and the motivation to innovate by adding production value was also minimal due to less risk, capital considerations, and market certainty. It was captive in nature, large and small in volume, and international buyers determined the purchase price. The price formed in Singapore by SICOM was a reference for transactions by natural rubber business actors. In addition to the SICOM stock exchange, the Tokyo Stock
Exchange (TOCOM) and the Shanghai future exchange also played a role in forming world natural rubber prices. In addition, the export option to use Dollars had a higher transaction value than absorbed by the supporting/intermediate processing industry.

With the fulfillment of raw materials and processing machines in the upstream sector, the next network element was the distribution sector (midstream). This sector required the availability of means of feasible transportation in a business manner by considering the costs and benefits obtained. Ahmadi (2020) stated that when talking about transportation, the private sector considered the factor of "smoothness." Smoothness here means not only roads free of obstacles but also the waiting time for loading and unloading (dwelling time) at the port. Although the distance from the company to the port - for example - is $60 \mathrm{~km}$ but smooth, it will save costs, compared to traveling $20 \mathrm{~km}$ in traffic. It relates to the delivery contract between the seller and the buyer. Of course, to avoid penalties, smooth operation is a must in a sustainable business transaction. If it is not smooth and the seller does not fulfill the commitment to deliver the goods on time, it will be detrimental for business.

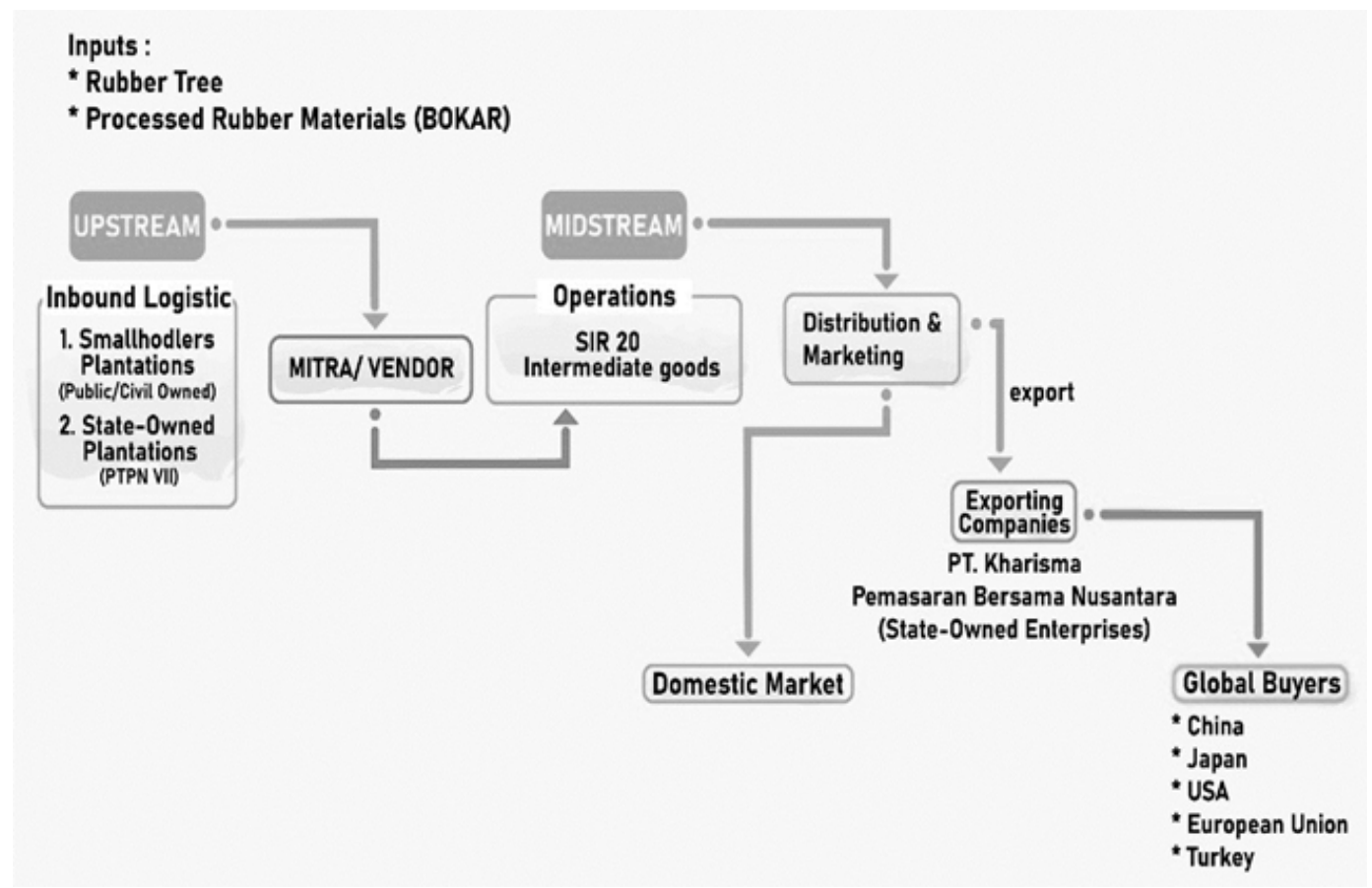

Figure 4. Rubber Value Chain by PTPN VII (Sumatera Postm 2020; PTPN 7, 2020) 
Apart from transportation, the midstream sector was also affected by the banking or financial sector. Getting access to capital and easy payments from banks was an essential factor for the rubber commodity value chain. As the top first supplier country of natural rubbers for South Korea in product HS 4001, Indonesia Trade Promotion Centre (ITPC) Busan (2020) mentioned that the existence of an export credit mechanism, payment of Letter of Credit and insurance, made it easier for rubber business actors to catch up and compete in the market. Nair (2018) stated that a hedging mechanism against foreign currency exchange rates (hedging) could be risk mitigation for the fluctuation of international rubber trade transactions. For example, a transaction is made on September 29, 2020 , at an exchange rate of $1 \mathrm{USD}=\mathrm{Rp} .14,500$. Hence, if a business actor uses the hedging facility, if, on October 1, 2020, the exchange rate becomes Rp. 15,000, then the business actor only pays the agreed exchange rate on September 29, 2020, thus avoiding the risk of Rp. 500 per 1 USD. Of course, all of this cannot be separated from the support of the financial and banking sectors. Thus, the resulting prices can be competitive and have an internationally recognized quality.

\section{OPPORTUNITY FOR DOWNSTREAM RUBBER PRODUCT INDUSTRY: TIRE INDUSTRY, RUBBER ASPHALT, AND AUTOMOTIVE SPARE PART INDUSTRY}

The next strengthening option was the initiation of attracting investment in downstream companies of processed rubber products outside South Sumatra. One of the representatives of the South Sumatra industry at the Coordination Meeting to increase trade within the Indonesia-Malaysia-Thailand Growth Triangle (IMT-GT) framework, on May 17, 2019, coordinated by the Directorate General of International Trade Negotiations at the Ministry of Trade in Palembang and attended by one of the authors, mentioned that the local government has attempted to submit an investment offer in one of the tire companies in Surabaya. The meeting also discussed the development of Special Economic Zones (SEZs). However, it was still constrained by the difficulty of obtaining processed raw materials for supporting rubber products managed by brokers SICOM and TOCOM. Thus, the decentralized offshore option would not be selected by the company. The tire company was chosen because of its capacity as the largest company that would absorb raw rubber materials at the domestic level in the tire industry by $65 \%$ and manage to produce final goods at the downstream level. This large industry has subsidiaries managed vertically with upstream suppliers and supporting industries for raw materials, although some components still depend on imports (see Figure 5). It is what the authors observed, which revealed that it was not a rational choice to move the production base from Java to South Sumatra because they already had their integrated solid line of the value chain and remained centralized. Moreover, it became another challenge and initial to order the SEZ to trigger the investment and the sustained decision for the downstream industry of natural rubber.

Can Indonesia or the regions have their own tire industry? The answer is it must and can. The tire industry is a necessity because it is a strategic industry. No technology can replace the role of tires made of rubber (Arsyad, 2020). All Formula 1 cars on the highway use tires. Tires are still made of rubber in a round shape. Since the $19^{\text {th }}$ century, tires remain the same. Even though in the past yarn was used and now replaced by nylon, but rubber as the main raw material in making tires is still in use. Tires weighing 7-9 $\mathrm{kg}$ cost Rp. $3,000,000 /$ piece. It shows the economic potential in the tire industry. The manufacture of tires can be from ordinary to high technology (for the manufacture of Formula 1 racing car tires, which only weigh $7 \mathrm{~kg}$ ). We can create a small-scale tire factory. It requires a total investment of around USD 40 to 50 million. This factory has the potential to absorb around 1,400 employees. It certainly will open up jobs. Based on Bridgestone's experience, sales turnover can reach Rp. 8 trillion/year. However, something must be sacrificed, namely, land. Bridgestone closed around 30 ha of rice fields and 100 ha of plantations for building factories.

Another important note is the increasing customer sophistication and the importance of high-quality products. Arsyad (2020) stated that Bridgestone products belong to the premium category and become official sponsors of 


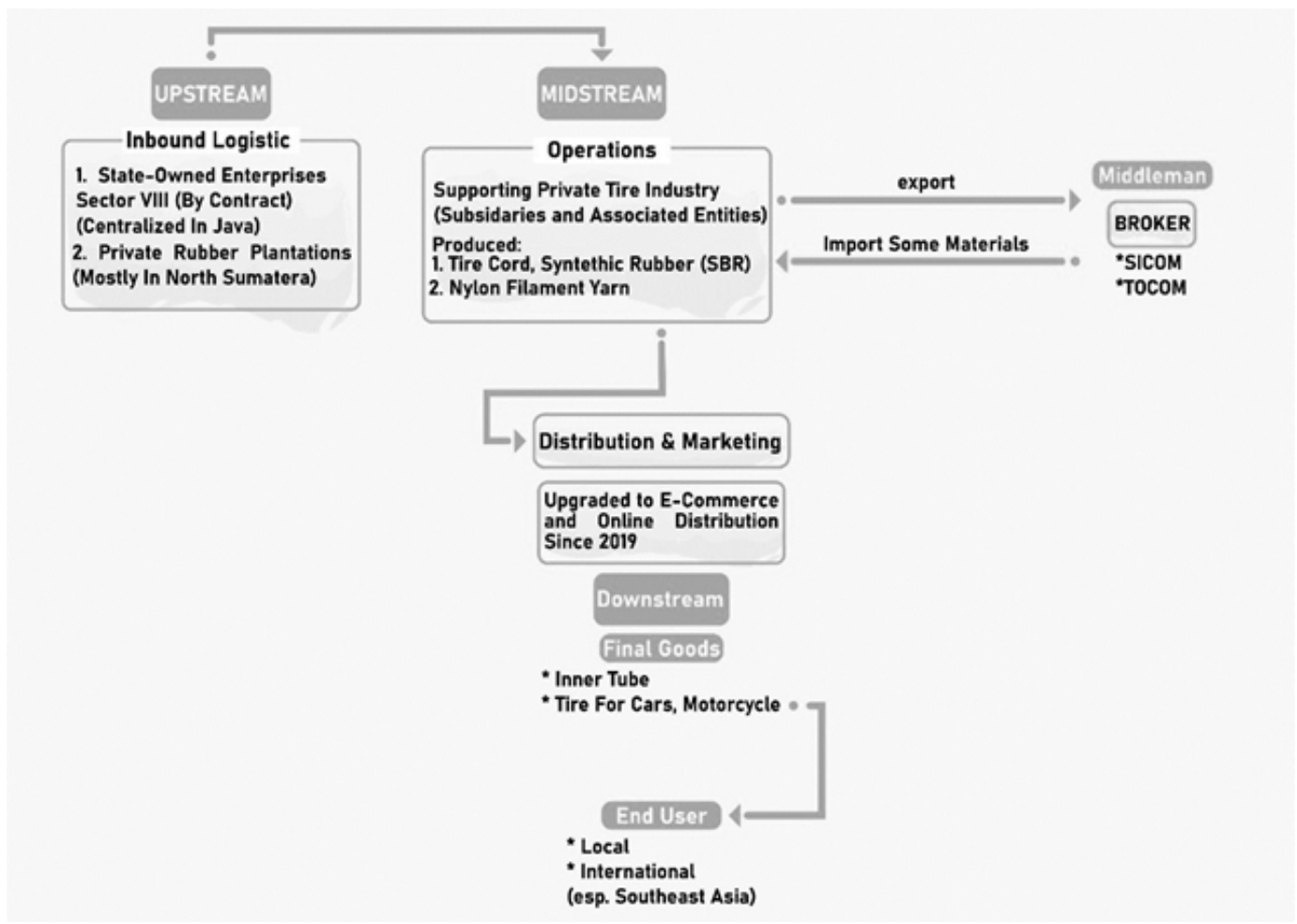

Figure 5. Rubber Value Chain by Tire Industry Companies (Leading Firm) (Arsyad, 2020; Bridgestone Indonesia, 2020; PT.Gajah Tunggal Tbk, 2020)

Formula 1 races. It is due to the quality of the selection of raw materials. Engineers were directly brought in from Japan to carry out the Quality and Assessment of raw materials. Only Bridgestone performs the procedure. Premium products have implications for premium/high selling prices compared to competitors. However, consumers feel happy. Consumers assume that tires with low prices also have lower quality (KW1, KW 2). They are willing to pay dearly for quality. Nothing can kill a tire company, except corruption, because the need for tires will always be there. In 1954, Indonesia had its tire factory called PT. Intirub or PT. Indonesia Tire \& Rubber Works (BUMN), located at Jl. Cililitan Besar, DKI Jakarta, even issued a famous tire brand at that time, "PALEMBANG".

The domestic market should not be underestimated. Domestic market potential, such as latex to rubber asphalt, are promising products in the future. It is the plan of the Mayor of Musi Banyuasin, Alex (2020), who stated that with the presidential instruction stating roads must be asphalt mixed with rubber, the need for rubber would be quite high. Of course, it could lead to benefits for the region. On that basis, Musi Banyuasin has arrived at the commissioning - after the engineering and procurement stages - of rubber asphalt products and has been ready to meet the domestic demand for rubber asphalt supplies.

In addition, the tendency to localize the automatic industry is getting stronger, given the positive market absorption in both the local market and international demand. Indonesia, however, does not yet have an original local brand as big as Japan, such as Toyota and Daihatsu, or even the pride of Malaysia, Proton. The automotive industry in the country is the largest in Southeast Asia when assessed based on annual domestic sales data. This localization will be followed by investment, manufacturing, and research, all of which can be used as technology transfer. Chairman of the Association of Indonesian Automotive Industries (GAIKINDO) Yohannes Nangoi said that technology transfer in Indonesia was already underway (Gaikindo, 2020). In other words, Indonesia has been independent in the affairs of the car industry, although it has not been $100 \%$. It certainly can strengthen the downstream sector 
of processed rubber products, which has targeted the automotive industry line from the start. Unfortunately, in the upstream sector, which is related to the technology development program for natural and synthetic rubber industries, which should be targeted to be achieved in 2019 in the 2015-2035 RPIN, technically, it has not been implemented for the South Sumatran scale because the mid-stream stops at the value of intermediate goods. Regulations on providing incentives for industries that carry out $R \& D$ activities in domestic industrial development are contained in the Government Regulation Number 45 of 2019 concerning the Calculation of Taxable Income and Payment of Income Taxes in the current year. Apart from being recently issued in September 2019, the derivative regulations also have not been issued. Therefore, the potential benefits of the localization of the automotive industry and the hope for the development of rubber-based supporting industries remain on the talk.

Even though there has been a transfer of technology by Daihatsu, it is limited to its initiative, not fully supported by the government to motivate industry to strengthen its innovation base through $R \& D$. Astra Daihatsu Motor (ADM) Marketing Director Amelia Tjandra said that so far, the government has not provided support even though there have been investments and technology transfer projects. The Indonesian Automotive Industry Association (GAIKINDO) Yohannes Nangoi mentioned that technology transfer in Indonesia was underway. There are several $R \& D$ facilities of the car manufacturer in the country, but the most complete facility is Daihatsu. A number of products born by $R \& D$ Daihatsu include Luxio, as well as collaboration products with Toyota, namely Rush-Terios, Agya-Ayla, Avanza-Xenia, and Calya-Sigra. It seems that $95 \%$ of Agya and Ayla cars have been done in Indonesia starting from the design (Gaikindo, 2020).

\section{THE STAGNANCY AND PROSPECT OF THE DEVELOPMENT OF TANJUNG API-API SEZ}

Tanjung Api-Api SEZ has a geo-economic advantage of being located in the largest rubber and palm oil-producing region in Indonesia. The area has been prepared to maximize industrial activities, export, import, and other economic activities with high economic value and specialization in production. Hence, it can accelerate regional development and as a breakthrough model for regional development for economic growth.

The findings revealed that geographically, the area is very strategic for international trade. Banyuasin has several potentials in terms of natural resources. The condition of land resources in Banyuasin Regency consists of wet and dry land. Nearly $80 \%$ of the area is a stretch of wetland in the form of lowland swamps, peatlands, and tidal lowlands. About 20\% is dry land used for yards and settlements, plantations, fields, and others (Helvan, 2020). A special area with tidal swamp ecosystems split by river flows into deltas forms lowlands with peat spread along the east coast. Meanwhile, along the downstream coast of the Musi and Komering Rivers, there are lebak areas. Tanjung Api-Api SEZ is located in the Banyuasin II District. With a very strategic location in the northern region and directly facing the Bangka Strait and the deep ocean, it makes this area feasible to become an integrated industrial area. The meaning of integration is where the company establishes a factory, and the factory output can come out through an outlet in a deep seaport.

Referring to the early history of the formation of the SEZ, the Provincial Government of South Sumatra has seen a great opportunity in the context of economic acceleration in the Tanjung Api-Api region. At the beginning of the planning, the provincial government made the concept of an SEZ structure with three main areas, including the production of raw materials, load production, a place where the industrialization process is carried out from raw materials to finished or semi-finished materials, and the loading node or port area as an inlet/outlet for post-production products in the production load node area.

This projection has been the focus of the local government before forming regulations regarding SEZ regulated by the central government. The central government has a program in line with the economic acceleration program through SEZ formation in strategic areas in Indonesia. The provincial government then proposed the Tanjung Api-Api area to become an SEZ in 
the projection of the national plan. This application was later accepted and became one of the top priorities among other SEZs in Indonesia. The SEZ was designated in 2014 through Government Regulation No. 51 of 2014, with an operational preparation period of three years, extended by one year, and evaluated for one year, with a maximum total time of five years. Unfortunately, until this research was done, Tanjung Api-Api was still in the progress of land cleaning and could not meet the target of development time.

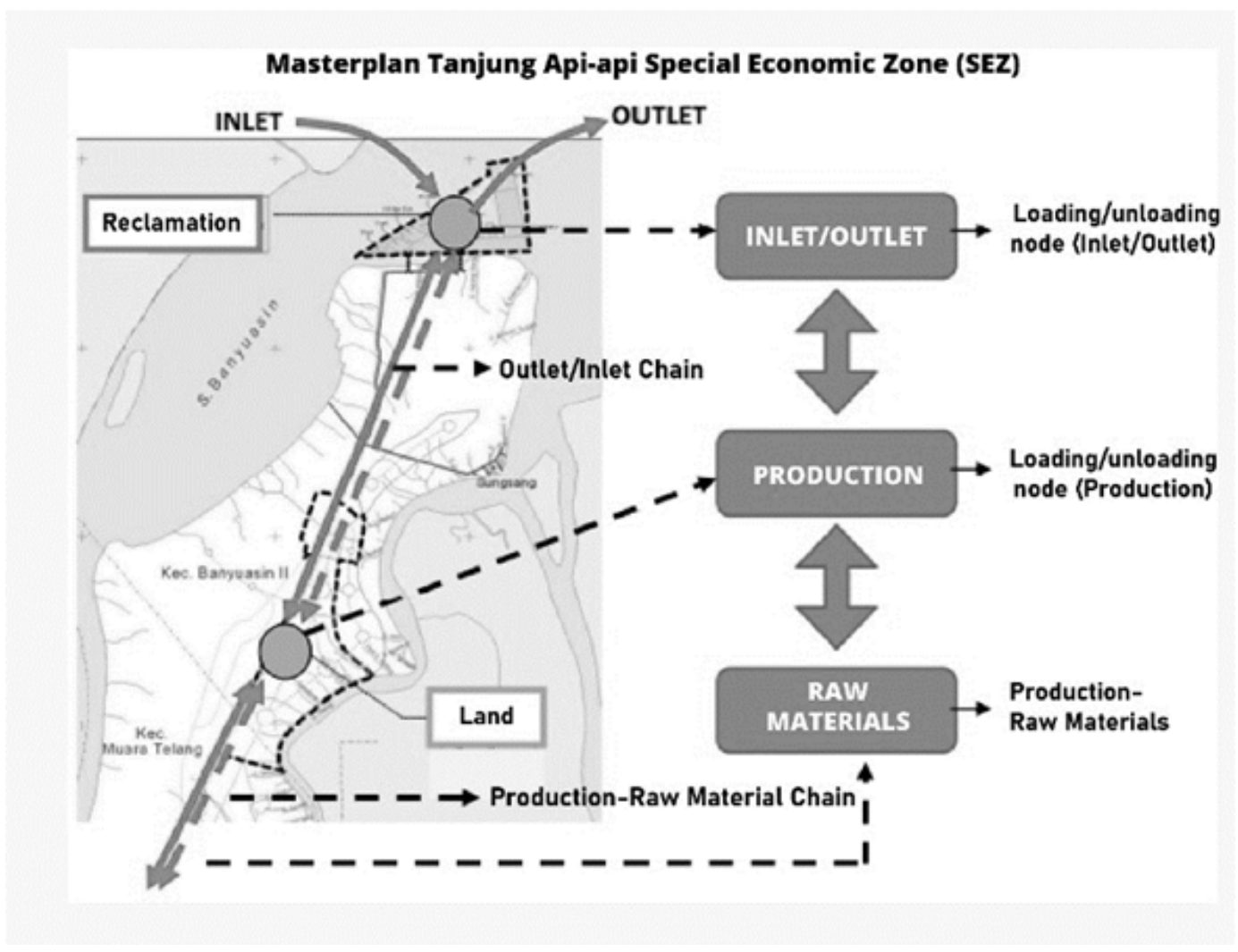

Figure 6. The Initial Structure of Tanjung Api-Api SEZ During the Submission Process (PT. SAS, 2020)

What are the bottlenecks causing this SEZ not to be materialized? This research discovered several points. First, the port landscape. Ideally, ports that can become outlets for export-import activities are deep seaports, such as Tanjung Priok, Tanjung Perak, and Belawan. Although geographically, the port directly faces the ocean/high seas, the sedimentation or underwater contours of Tanjung Api-Api port is considered very low, thus not suitable for berthing for large tonnage ships carrying containers of output. A suitable port as a deep seaport is Tanjung Carat. SEZ in Tanjung Api-Api was designed with an area of 2030 ha and added to the port area development in the Tanjung Carat area. However, the central government in its strategic plan only accepts proposals for a special economic area in Tanjung Api-Api covering an area of 2030 ha without the development of a port in Tanjung Carat. The establishment of an SEZ began with a land clearing process. The initial stages of the SEZ development began in 2015 with a land acquisition plan covering an area of 217 ha. In implementing land acquisition until this data search was carried out, land clearing could only be carried out for an area of 63 ha. Obstacles to the acquisition were based on several issues, including government land acquisition that could only be carried out for the public interest, while SEZs were not a category of areas for the public interest. 
In addition, the problems faced were regulations, budgets, and land prices, which were getting more expensive. In 2017, the area used as an SEZ faced licensing problems. In 2014, it was considered a non-peat area, but in 2017, it was included in the peat area on an indicative map.

Second, execution. In theory, Tanjung Api-Api SEZ has been included in the central government's plan as an integrated economic center. Continuing from the first point, because there was still a communication gap between the central and regional governments, the execution of this area was difficult to realize. It was related to land acquisition. Who has the authority to acquire land? Land acquisition was also related to the cost of compensation and the potential for resistance among the surrounding community, not to mention the environmental aspect. Who is entitled to issue an environmental impact analysis? Will all these costs be borne by business actors? With the consideration of profit and loss, business actors will think twice about being able to realize their investment if regulation and execution are uncertain.

The interview with Helvan (2020), the Operation Supervisor of PT. Sriwijaya Mandiri Sumsel (SMS), assigned to develop a special economic zone, revealed that Tanjung Api-Api as an SEZ has great opportunities for economic acceleration for the region and society. Post-production flow of finished or semi-finished goods could cut costs, especially the cost of shipping goods. Access to goods from South Sumatra has been using the Panjang Port Area, quite far from this province. The development of the SEZ has attracted foreign investors. BUPP has made an MoU with an investor from Thailand in 2019 regarding the construction of a coconut milk factory and export, as well as an Indian company Indorama engaged in coal. However, the MoU has not been realized considering there are still many problems in Tanjung Api-Api SEZ, especially the absence of a plan to develop a visible port, namely the port in Tanjung Carat. This condition should be of greater concern in the acceleration of SEZ development because accelerating the development and realization of Tanjung Api-Api SEZ can impact both regions and communities engaged in the upstream sector.

\section{CONCLUSION}

The government must evaluate local and international companies' existence while finishing the establishment of Tanjung Api-Api Special Economic Zone immediately. Besides, the policymakers need to grab the opportunities for inward foreign direct investment to support a competitive advantage in the value-added industrial sector. It can be done by creating a clear roadmap, bureaucratic efficiency between national and local governments, and sustainable programs related to industry priorities to increase natural competitiveness resource-based processing. To increase our rubber commodity's values, the option of establishing a tire industry, domestic absorption through rubber asphalt, or the automotive industry supporting sectors as a form of downstream of rubber commodities-is the potential strategic policy agenda. By doing this, it is highly possible to protect and provide a fair price for rubber farmers.

\section{ACKNOWLEDGEMENT}

The authors would like to address their gratitude to those who contributed to the writing of this paper. This study was partly the results of the Science, Technology, and Art (SATEKS) research funded by the Research Institute of Sriwijaya University.

\section{REFERENCE}

Ahmadi, N. (2020, September 2020). South Sumatra Processed Rubber Products Value Chain Efficiency. (M. Y. Yusa, Interviewer)

Alex, D. R. (2020, September 9). Commitment of Local Government in Value-Added Activities for Musi Banyuasin Rubber Products. (M. Y. Yusa, Interviewer).

Arsyad, J. M. (2020, October 28). Downstream Industry PT. Bridgestones Indonesia. (M. Y. Yusa, Interviewer).

ASEAN. (2015). ASEAN Guidelines for Special Economic Zones (SEZS) Development and Collaboration. Jakarta: ASEAN.

ASEAN. (2019). ASEAN Integration Report 2019. Jakarta: ASEAN Secretariat.

BAPPEDA Sumsel. (2011). Kawasan Terpadu Tanjung Api-Api. Retrieved September 08, 2020, from https://bappeda. sumselprov.go.id: https://bappeda.sumselprov.go.id/user files/files/1427701207 628736893.pdf

BAPPENAS. (2011). Master Plan Percepatan dan Perluasan Pembangunan Ekonomi Indonesia (MP3EI) 2011-2025. Jakarta: Bappenas.

BPS. (2019). Indonesian Rubber Statistics 2018. Retrieved February 23, 2020, from https://www.bps.go.id/publication/ 
2019/11/22/c73bdba12c1f122edae18a29/statistik-karet indonesia-2018.html

Bridgestone Indonesia. (2019, June). Annual Report bridgestone Indonesia MNC tire industry company. Retrieved February 5, 2020, from www.bridgestone.com: https://www. bridgestone.com/corporate/library/annual_report/pdf/bs_ annual_2019_operational.pdf

Cattaneo, O., \& S. Miroudot. (2013). From Global Value Chains to Global Development Chains: An Analysis of Recent Changes in Trade Patterns and Development Paradigms, in Zedillo. E. and st B. Hoekman (eds.), 21 Century Trade Policy: Back to the Past?, volume in Honor of Professor Patrick Messerlin, New Haven, CT: Yale University Press.

Cattaneo, O., Gereffi, G., Miroudot, S., Taglioni, D. (2013). Joining, Upgrading and Being Competitive in Global Value Chains: A Strategic Framework. Policy Research Working Paper, No.6406, World Bank, Washington, D.C. Retrieved September 23, 2020, from https://openknowledge.world bank.org/handle/10986/14444

CNN Indonesia. (2019, October 5). Trade War and New Competitors, Reasons for Shrinking Rubber Prices. Retrieved August 12, 2020, from https://m.cnnindonesia.com/ ekonomi/20191004174827-92-436829/perang-dagangdan-pesaing-baru-alasan-harga-karet-menciut

Dube, C., Matsika, W., \& Chiwunze, G. (2020). Special economic zones in Southern Africa: Is success influenced by design attributes? New York: United Nations University.

Fauzi, I. R. (2013). Alternatif Strategi Pengembangan Industri Barang Jadi Karet di Indonesia. E-Journal Warta Perkaretan Pusat Penelitian Karet, Vol 32 (2), 55-64.

Gaikindo. (2020, September 3). Sekilas Catatan Perjalanan Industri Otomotif Indonesia. Retrieved October 10, 2020 from Berita Ekonomi dan Industri: https://www.gaikindo.or.id/sekilascatatan-perjalanan-industri-otomotif-indonesia/

Gereffi, G., \& Frederick., S. (2010). The Global Apparel Value Chain, Trade and the Crisis: Challenges and Opportunities for Developing Countries. Policy Research Working Paper; No. 5281. World Bank. Retrieved September 24, 2020, from https://openknowledge.worldbank.org/handle/10986/3769

Ginting, B., Sembiring, R., Siregar, M., \& Abduh, A. (2017). Harmonization of the Special Economic Zones for the Management of Sei Mengkei: Optimizing the Downstream Oil Palm Industry in North Sumatra to Support Regional Development, Legal Studies. International Journal of Economic Research Vol 14 (20), 311-330.

Harahap, N. H., \& Segoro, B. A. (2018). Analisis Daya Saing Komoditas Karet Alam Indonesia ke Pasar Global. TRANSBORDERS: International Relations Journal, Vol.1 (2), 130-143.

Helvan, G. (2020, September 04). Kawasan Ekonomi Khusus Tanjung Api-Api. (S. M. Aisyah, Interviewer).

IGF. (2018). Singapore: Downstream Linkages. Ottawa: Intergovernmental Forum on Mining, Minerals, Metals and Sustainable Development.

ITPC Busan. (2020, July). Potensi Indonesia di Pasar Natural Rubber Korea Selatan. Retrieved September 07, 2020, from www.itpc-busan.kr: https://itpc-busan.kr/wp-content/ uploads/2020/07/NATURAL-RUBBER-DI-KOREA-ITPC-web-ok .pdf
Kemenperin. (2015, June). Rencanalnduk Pembangunan Industri Nasional (RIPIN) 2015-2035. Retrieved July 20, 2020, from www.kemenperin.go.id: https://www.kemenperin.go.id/ ripin.pdf

Kompas. (2011, November 16). Forum Investasi ASEAN Dibuka Hari ini. Retrieved December 10, 2019, from http://bisnis keuangan.kompas.com/read/2011/11/16/09581797/Forum. Investasi.ASEAN.Dibuka.Hari.ini

Low, P., \& Tijaja, J. (2013). Global Value Chain and Industrial Policies. E15 Initiative. Geneva: ICTSD and World Economic Forum. Retrieved July 23, 2020, from http://www.ictsd. org/sites/default/files/research/E15_GVCs_Low\%20Tijaja_ FINAL.pdf

Muradov, K. (2017). Determinants of country positioning in global value chain. The 25th International Input-Output Conference (pp. 1-74). Atlantic City: The 25th International Input-Output Conference.

Nair, S. T. (2018). The Effects of Financial Crisis on Hedging Efficiency of Indian Rubber Future Markets. Financial Statistical Journal vol. 1 no. 3, 1-7.

Nasruddin et.al. (2012). Road map for the development of natural rubber into spare parts for transportation equipment in the Tanjung Api-Api industrial area, Banyuasin Regency, South Sumatra Province. Palembang: Industrial Research and Standardization Agency.

Organization for Economic Co-operation and Development and World Trade Organization. (2013). Aid for Trade at a Glance 2013: Linking to Value Chains, Paris: OECD. Retrieved September 22, 2020, from https://www.oecd.org/g20/ topics/development/aidfortradeataglanceconnectingtoval

Östensson, O. (2020). The Potential Of Extractive Industries As Anchor Investments For Broader Regional Development. WIDER Working Paper 2020/87. Helsinki: UNU-WIDER.

Parizade, B., \& Mulyana, A. (2014). Strategy for Accelerating the Development of the Downstream Rubber and Oil Palm Industry in South Sumatra. Jurnal Manajemen dan Bisnis Sriwijaya (JMBS), Vol.12 (2), 91-98.

Patunru, A. A. (2015). Trade protectionism in Indonesia: Bad times and bad policy. Lowy Institute for International Policy, 1-30.

Porter, Michael E. (1985). Competitive Advantage: Creating and Sustaining Superior Performance. University of California: Free Press.

PT. Gajah Tunggal Tbk. (2020, June 19). Annual Report the tire industry company PT Gajah Tunggal tbk. Retrieved September 22, 2020, from www.gt-tires.com: https://www. gt-tires.com/indonesia/corporate. asp? menuid $=3 \&$ classifica tion $=19$ \& subid $=39$ \&language $=1$

PT. SAS. (2020). Master Plan for the Tanjung Api-Api SEZ. PT. Sriwijaya Alam Segar.

Sumatera Post. (2020, October 22). DPRD Sumsel Berharap PTPN VII Garap Produk Jadi. Retrieved October, 2020, from Sumatera Post: https://journal.umy.ac.id/index.php/jhi/ article/view/7943/pdf_21

Syarifa, L. F., \& Tistama, R. (2020). Analisis Kinerja dan Prospek Komoditas Karet. Radar Journal Vol. 1 No. 2, 1-7.

United Nations Conference on Trade and Development. (2013). Global Value Chains and Development: Trade-Related Targets, Investment and Value Added Trade in the Global Economy. Geneva: UNCTAD. Retrieved July 15, 2020, from 
https://unctad.org/system/files/official-document/di ae2013ae2013d1_en.pdf

Zeng, D. Z. (2012). China's Special Economic Zones and Industrial

Clusters: Success and Challenges. Cambridge: Lincoln Institute of Land Policy. 